\title{
Civilian Health and Medical Program of the Department of Veterans Affairs
}

National Cancer Institute

\section{Source}

National Cancer Institute. Civilian Health and Medical Program of the Department of Veterans Affairs. NCI Thesaurus. Code C157362.

A comprehensive health care program, administered by the Department of Veterans Affairs, designed to provide health care services for military veterans. 